\title{
IE MILITÊR-HISTORIESE EN ARGIVALE DIENSTE VAN IE DEPARTEMENT VAN VERDEDIGING
}

\section{INLEIDING}

In hierdie bydrae word 'n oorsig gegee van die ontstaan, die ontwikkeling, die funksies en die benutting van die huidige MHAD van die Departement van Verdediging.

In die loop van dié oorsig sal die leser herhaaldelik 'n aantal vakterme teenkom wat dalk tot misverstand kan lei. Hulle is die volgende: Argief, orgiefbewaarplek en argivalia.

Die term argief word in vakkundige kringe gebruik om 'n dokumenteneerslag aan te dui. Deur argiewe egter bloot as dokumenteneerslae te beskou, word die begripsinhoud van die term nie ten volle verklaar nie. Ten einde tot 'n volledige begripsverklaring van wat argiewe is te kom, kan kortliks op onderstaande aspekte gelet word.

Algemeen gesproke kan gesê word dat 'n argief die dokumenteneerslag van' $n$ amptelike of private instansie is wat in die loop van 'n doelgerigte administratiewe proses ontstaan het.

'n Argief moet te gener tyd as bloot 'n versameling van dokumente beskou word nie, maar uitsluitlik as die dokumenteneerslag van 'n instansie (amptelik of privaat) wat as gevolg van 'n bepaalde groeiproses tot stand gekom het.

Die argiefvormende bronne is dus die sakewêreld of die verskillende administratiewe sfere.

In hierdie perpektief gesien, moet daar tussen openbare en private argiewe onderskei word. Omdat dit in hierdie oorsig oor openbare argiewe- sal gaan, kan laasgenoemde verder ontleed word.

In die Argiefwet, (Wet No. 6 van 1962), word argiewe, en dus ook openbare argiewe, omskrywe as:

Alle dokumente of stukke wat in die loop van die bestuur van sake in 'in staatskantoor of ' $n$ kantoor van 'n plaaslike owerheid in so 'n kantoor ontvang of geskep is en waarmee daar dan nie, volgens die aard daarvan of ingevolge ' $n$ ander parlementswet, gehandel word anders as ooreenkomstig of ingevolge die bepalings van hierdie wet nie.

In die sin van openbare argiewe, het die uitdrukking argiewe nie net op dokumente of stukke wat in 'n argiefbewaarplek bewaar word, betrekking nie; maar ook op alle dokumentasie (verouderd of in lopende gebruik) van 'n staatskantoor of 'n plaaslike owerheid. Alle inkomende stukke, memoranda, voorleggings en aantekeninge wat opgestel word en alle registers, vorms en ander kantoorrekords wat gehou word, is vir die doeleindes van die Argiefwet en - regulasies, argiewe.

Militêre argiewe is ook openbare argiewe, maar behels uitsluitend die argiewe van die Departement van Verdediging.

Lie term argiefbewaarplek word gebruik om die gebou, waarin argiewe gehuisves word, aan te dui.

Omdat daar meer as slegs argiewe in 'n argiefbewaarplek bewaar word, word die oorkoepelende term argivalia gebruik om die kollektiewe inhoud van 'n argiefbewaarplek aan te dui.

Met voorafgaande begrippe duidelik omlyn, kan nou oorgegaan word om die ontstaan en ontwikkeling van die Militêr-Historiese en Argivale Dienste te beskrywe. 


\section{ONTSTAAN EN ONTWIKKELING}

\section{a. Die periode 1914-1939}

\section{i. Die Informasie Buro}

Die ontstaan van die Militêr-Historiese en Argivale Dienste kan teruggevoer word na die instelling van 'n Informasie Buro op 1 Oktober 1914 aan die Verdedigingshoofkwartier. Die doel van die Buro was om as amptelike inligtingskakel tussen die troepe in Suidwes-Afrika en die publiek te dien. Met die afsluiting van die veldtog in Suidwes-Afrika het die Informasie Buro opgehou om te funksioneer.

\section{ii. Hoofregisterkantcor - Imperiale Dienskontingente}

Die voortsetting van die Suid-Afrikaanse oorlogspoging het die inskakeling van die Suid-Afrikaanse troepe by die Imperiale magte tot gevolg gehad. 'n Nuwe skakelkantoor, soortgelyk aan die Informasie Buro is op 15 September 1915 ingestel, met die aanstelling van Kapt. A. K. le R. Harvey as Hoof van die Hoofregisterkantoor vir Imperiale Dienskontingente.

Vir die effektiewe uitvoering van sy funksies was dit nodig dat die Hoofregisterkantoor gedurende die oorlog persoonlike lêers vir elke vrywilliger open wat in 'n Imperiale cenheid diens gedoen het, waarop die nodige diensbesonderhede bygehou is.

\section{iii. Die Argiefafdeling}

Die geweldige hoeveelheid administratiewe werk wat aan moderne oorlogvoering verbonde is, was direk verantwoordelik vir die feit dat die Departement van Verdediging na die Eerste Wêreldoorlog oor so 'n groot dokumenteneerslag beskik het, dat dit die eerste uniale departement was wat 'n argiefbewaarplek geregverdig het. Dit blyk uit die feit dat. die Bewaarder van Oorlogsargiewe, mnr. G.H. Byrnes, sy werksaamhede in Augustus 1919 begin het, terwyl dr. C.G. Botha eers op 29 Oktober 1919 as die eerste hoofargivaris van die uniale argiefdiens aangestel is.

Die beëindiging van die vyandelikhede in 1918 het tot gevolg gehad dat eenhede wat vir oorlogsdoeleindes gemobiliseer is, ontbind is en dat sodanige ontbonde eenhede hulle argiewe na die Sekretaris van Verdediging moes oorplaas, alwaar dit deur die Klerk in beheer van Oorlogsargiewe ontvang is, het, benewens die omvangryke administratiewe lêerneerslag, ook 'n groot hoeveelheid van verskillende soorte persoonlike lêers van vrywilligers ingesluit.

Hierdie akkumulasie het die Sekretaris van Verdediging genoop om daadwerklike stappe ter versorging van die oorlogsargiewe te neem.

Reeds in Januarie 1919 is samesprekings oor die byeenbring en köordinering van oorlogsargiewe gevoer. Hieruit voortvloeiende is 'n argiefafdeling onder direkte beheer van die Sekretaris van Verdediging gestig. In Augustus 1919 het mnr. G.H. Byrnes, wat as Bewaarder van Oorlogsargiewe 
aangestel is, sy werksaamhede met betrekking tot die versorging van oorlogargiewe begin.

In Oktober 1919 het die Sekretaris van Verdediging 'n omsendbrief aan alle militêre afdelings gestuur, waarin hy die basiese plan vir die versorging van die oorlogsargiewe uiteengesit het. Hiervolgens sou die argiewe in die volgende kategorieë ingedeel word:

(a) Permanente argiewe: d.i. die argiewe wat as van militêrhistoriese belang geag is. Aan hierdie groep argiewe sou spesiale aandag geskenk word.

(b) Persoonlike lêers. Hierdie kategorie lêers is nie as waardevol genoeg geag om in die permanente argiewe opgeneem te word nie. Die verskillende soorte persoonlike lêers van 'n vrywilliger moes geamalgameer word, sodat elke vrywilliger wat in die oorlog gedien het, slegs een persoonlike lêer sou hê.

(c) Finansiële argiewe. Die groep rekenpligtige argiewe wat nie by groepe (a) en (b) ingedeel kon word nie, moes slegs bewaar word totdat dit nie meer gebruik word nie. Daarna moes dit as efemere argiewe vernietig word.

(d) Ander argiewe oftewel die dokumenteneerslag van kampe, hospitale, depots, basisse, e.d.m. wat nie vanuit 'n militêr-historiese oogpunt belangrik genoeg geag is om permanent te bewaar nie en wat eventueel vernietig sou word.

\section{iv. Sentralisasie van oorlogsargiewe}

Die doel van die plan was om die verskillende soorte persoonlike lêers ${ }^{1}$, sowel as die res van die oorlogsargiewe, te sentraliseer.

Die sentralisasie van oorlogsargiewe het kortliks soos volg verloop:

Op 25 November 1919 is alle werksaamhede in verband met die uitreiking van die Eerste Wêreldoorlog se oorlogsmedaljes van die Afdeling van die Adjudant-generaal, na die Hoof van die Hoofregisterkantoor, Imperiale Dienskontigente, oorgedra. Tegelykertyd is die persoonlike rekords van vrywilligers wat in die Suidwes-Afrikaveldtog gedien het, ook van die Adjudant-generaal se kantoor na die Hoofregisterkantoor oorgeplaas.

Op 15 Januarie 1920 is die pos Hoof van die Hoofregisterkantoor, Imperiale Dienskontigente, afgeskaf en is dit deur die pos van Stafoffisier Oorlogsregisters vervang. Die Stafoffisier Oorlogsregisters was direk aan die Hoof van die Generale Staf vir die uitvoering van sy pligte verantwoordelik.

In Julie 1920 is die Afdelings van die Bewaarder van Oorlogsargiewe en dié van die Stafoffisier Oorlogsregisters onder lg. geamalgameer. Die persoonlike lêers van vrywilligers wat in besit van die Bewaarder van Oorlogsargiewe was, is deur die Stafoffisier Oorlogsregisters oorgeneem. 
Vanaf 11 Oktober 1921 was die Stafoffisier Oorlogsregisters vir die uitvoering van sy pligte direk aan die Adjudantgeneraal verantwoordelik.

Gedurende dieselfde jaar is die argiewe van die Inspekteurgeneraal van die S.A. Berede Skutters, die Kommissaris van Teruggekeerde Soldate en dié van die takkantoor van die Imperiale Betaalmeester deur die Stafoffisier Oorlogregisters oorgeneem, toe dié poste afgeskaf is.

Hierdeur was die sentralisasie van die oorlogsargiewe afgehandel.

Die funksies van die Stafoffisier Oorlogsregisters was hoofsaaklik die afhandeling van sekere verpligtinge wat die Departement van Verdediging ten opsigte van oud-vrywilligers moes nakom.

Dergelike verpligtinge het o.m. ingesluit: Die uitreiking van gedenkplate, gedenkskrifte, medaljes, oorlogsonderskeidingstekens, embleme en diensstate; die administratiewe werk verbonde aan oorlogsgraftes en die verstrekking van informasie aangaande diensbesonderhede van oud-vrywilligers. Benewens hierdie funksies was die Bewaarder van Oorlogsregisters, as 'n afsonderlike onderafdeling van die Stafoffisier Oorlogsregisters, steeds met die argivale versorging van die gesentraliseerde oorlogsargiewe belas.

Terwyl daar met die uitreiking van diensstate en medaljes voortgegaan is, is die werksaamhede van die Stafoffisier Oorlogsregisters in 1927 afgesluit en is die oorlogsargiewe van die Afdeling van die Adjudant-generaal na die Sekretaris van Verdediging oorgeplaas.

\section{b. Die periode 1927-1939}

$\mathrm{Na} 1927$ word daar nie meer in die departementele jaarverslae verslag gedoen oor die werksaamhede van die Stafoffisier Oorlogsregisters nie. Die eerste keer dat daar weer van die oorlogsargiewe verneem is, was in 1948 met die skeiding van militêre- en siviele argiewe ${ }^{2}$. Op hierdie stadium het die oorlogsargiewe by die Sekretaris van Verdediging berus. Hoewel die tydperk 1928 tot 1948 nie verantwoord kan word weens die gebrek aan bronne nie, kan in die lig van voorafgaande aangeneem word dat die betrokke argiewe vir die onderhawige tydperk deur die Sekretaris van Verdediging bewaar is.

\section{c. Die periode 1939 - hedle}

i. Afdeling Oorlogsregisters: 1939 - 1959

Kort na die uitbreek van die Tweede Wêreldoorlog is weer 'n Afdeling Oorlogsregisters gestig. Die funksies verbonde aan hierdie kantoor was ietwat uitgebreider as dié verbonde aan die eertydse Hoofregisterkantoor, Imperiale Dienskontingente, en kan kortliks soos volg opgesom word:

(a) Die byhou van persoonlike lêers ten opsigte van alle vrywilligers.

(b) Skakeling met die publiek in verband met alle ongevalle en die byhou van gedetailleerde ongevallestatistiek.

(c) Die uitreiking van toekennings, veldtogsterre, medaljes, dekorasies, invaliditeitskentekens en diensstate. 
(d) Administrasie verbonde aan ontslagte, ontheffings, oorlogsgratifikasies, boedels en pensioenaangeleenthede ten opsigte van vrywilligers.

(e) Die behartiging van welsynspligte veral met betrekking tot die naasbestaandes van diensdoende troepe.

(f) Die verstrekking van informasie oor krygsgevangenes. Hierdie informasie is van uitsendings van Radio Vatikaan, die vyandelike radio, uit koerante en deur samewerking met die Internasionale Rooikruis verkry.

$\mathrm{Na}$ die beëindiging van die oorlog was die Afdeling Oorlogsregisters, net soos in die geval na die Eerste Wêreldoorlog, belas met die afhandeling van na-oorlogse verpligtinge teenoor oud-vrywilligers. Die Afdeling Oorlogsregisters het egter as sodanig bly voortbestaan tot in 1959 , toe dit as 'n integrale deel van die toenmalige Krygshistoriese Afdeling ingelyf is.

\section{ii. Die Afdeling Unie-Oorlogsgeskiedenis 1943 - 1961}

Een van die interessantste militêr-historiese ontwikkelinge gedurende die Tweede Wêreldoorlog was die stigting van bogenoemde Afdeling.

Op 7 November 1943 het die toenmalige Eerste Minister, op voorstel van die Hoof van die Generale Staf, die samestelling van 'n U.V.M.-Historiese Advieskomitee goedgekeur.

In November 1945 is die naam van die onderhawige komitee met die goedkeuring van die Eerste Minister na Unie Oorlogsgeskiedenis Advieskomitee verander.

Vanaf 29 April 1946 het genoemde komitee direk aan die Eerste Minister in sy Afdeling Unie Oorlogsgeskiedenis, aanspreeklik geword.

Die betrokke komitee was belas met die maak van aanbevelings ten opsigte van alle aspekte rakende die Unie se Oorlogsgeskiedenis, t.w. militêr en siviel.

Op advies van hierdie komitee is amptelike oorlogsgeskiedskrywers deur die Departement van die Eerste Minister aangestel wat, in die Afdeling Oorlogsgeskiedenis, met die geskiedskrywing van die Tweede Wêreldoorlog belas is. Dit was verder die taak van hierdie geskiedskrywers om toepaslike argiewe vir sodanige geskiedskrywing byeen te bring en te orden. Vir hierdie doel is die Tweede Wêreldoorlog se oorlogsdagboeke en aanvullende materiaal wat by die SuidAfrikaanse Weermag (Afdeling Inligting van die AdjunkHoof van die Generale Staf) berus het, na die Departement van die Eerste Minister oorgeplaas.

Uit die pen van die geskiedskrywers, verbonde aan die Afdedeling Unie Oorlogsgeskiedenis, het die volgende werke verskyn:

(a) Crisis in the Desert (May - July 191:2), Cape Town, Oxford University Press, 1952.

(b) Sidi Rezeg Battles (1941), Cape Town, Oxford University Press, 1957. 
(c) War in the Southern Oceans, Cape Town, Oxford University Press, 1961.

Die Unie Oorlogsgeskiedenis Advieskomitee het in opdrag van die Eerste Minister sy werksaamhede op 31 Julie 1959 afgesluit.

Twee persone verbonde aan die Afdeling het egter nog voortgewerk tot 30 Junie 1961, toe die werksaamhede van die betrokke Afdeling finaal afgesluit is.

$\mathrm{Na}$ ontbinding van die Afdeling is die oorlogsdagboeke van die Tweede Wêreldoorlog en bygaande argiewe na die toenmalige Kryghistoriese Afdeling van die SAW oorgeplaas, terwyl ander materiaal wat deur die onderhawige Afdeling gedurende sy bestaanstydperk versamel is, soos boeke, kaarte, foto's en ander militêr-historiese materiaal na die Sentrale Argiefbewaarplek oorgeplaas is.

\section{iii. Die oprigting van die Afdeling Militêre Argief - 1948}

In 1948 het die toenmalige Minister van Verdediging bevind dat die posisie met betrekking tot die byeenbring, bewaring en versorging van militêr-historiese bronnemateriaal vir die periode na 1910 uiters onbevredigend was. Hy het hierdie toedrag van sake toegeskrywe aan faktore soos die gebrek aan vakkundige leiding insake die versorging van militêre argiewe, die feit dat militêre argiewe nie ooreenkomstig die bepalings van die Argiefwet vernietig word nie en die feit dat argiewe wat wel bewaar word, nie na 'n sentrale bewaarplek oorgeplaas word nie.

Ten einde hierdie toestand te verbeter, het die Minister in 1948 die vernietiging van alle militêre argiewe verbied. Nadat hy ondersoek laat instel het met betrekking tot die bewaring en versorging van militêre argiewe in die buiteland, is van Regeringsweë besluit om 'n militêre argiefbewaarplek op te rig.

Die stigting van die militêre argiefbewaarplek is op 14 Junie 1950 verwesenlik toe die Hoof van die Generale Staf die aanstelling van 'n Stafoffisier Argief gemagtig het. Die nuwe Afdeling het onder die Hoof van die Generale Staf, onder die Hoofsein-en-Inligtingsoffisier geressorteer en het as Militêre Argief bekend gestaan. Die Militêre Argief het eers in Januarie 1953 begin funksioneer, toe die Stafoffisier Argief aangestel is.

As gevolg van bogenoemde Regeringsbesluit om 'n militêre argiefbewaarplek op te rig, is in 1948 begin om die argiewe van die Departement van Verdediging, wat tot op hierdie stadium deur die Sekretaris van Verdediging bewaar is, in militêre- en siviele argiewe te verdeel.

Die militêre argiewe, waarvan die oorlogsargiewe van die Eerste Wêreldoorlog die belangrikste deel gevorm het, is na die Afdeling Militêre Argief oorgeplaas.

Die siviele argiewe van die Sekretaris van Verdediging het onder lg se beheer gebly. As synde die argiewe van 'n sekretariaat (van die Sentrale Regering) wat op 'n nasionale grondslag funksioneer, moes die argiewe van die Sekretaris 
van Verdediging na die Sentrale Argiefbewaarplek oorgeplaas word. Slegs 'n gedeelte van hierdie argiewe is sedertdien na gemelde argiefbewaarplek oorgeplaas.

\section{iv. Die Krygshistoriese Afdeling}

Die funksies van die Stafoffisier van die Militêre Argief was in hoofsaak die byeenbring, bewaring en versorging van militêr-historiese bronnemateriaal, die opstel van gepaste hoofstukke uit die Suid-Afrikaanse geskiedenis en die oprigting en administrasie van militêre museums. Sedert 1954 is die Militêre Argief ook belas met die hantering van heraldiese aspekte sover dit die Suid-Afrikaanse Weermag raak. Omdat die Afdeling se funksies veel meer as blote argivale aktiwiteite behels het, het die Hoof van die Generale Staf op 7 Januarie 1957 goedgekeur dat die Afdeling se naam van Militêre Argief na Krygshistoriese Afdeling verander word.

Gedurende 1959 het 'n besonder belangrike ontwikkeling plaasgevind toe die Afdeling Oorlogsregisters en die Krygshistoriese Afdeling onder die Senior Stafoffisier van lg Afdeling geamalgameer is en die Krygshistoriese Afdeling gedurende Augustus van dié jaar na die Afdeling van die Adjudant-generaal oorgeplaas is. Genoemde verandering is reeds op 31 Januarie 1955 deur die Minister van Verdediging goedgekeur. Tot tyd en wyl het daar niks van gekom voordat die Minister sy vorige besluit in hierdie verband op 16 Junie 1959 herbevestig het nie.

v. Die ontwikkeling tot volwaardige argiefbewaarplek

Die kwessie van 'n militêre argiefbewaarplek met wetstatus het reeds in die ontstaanjare van die Afdeling aandag geniet, dog dit is eers heel resent dat hierdie kwessie pertinent na vore getree het.

Die kern van die probleem was daarin geleë dat artikel 6 van die huidige Argiefwet voorsiening maak vir die oorplasing van alle argiewe in 'n staatskantoor of ' $n$ kantoor van 'n plaaslike owerheid wat nie ingevolge een of ander parlementswet deur ' $n$ bepaalde persoon in bewaring gehou moet word nie na 'n gepaste argiefbewaarplek sodra hulle dertig jaar of ouer is.

In die Verdedingswet van 1957 word nie voorsiening gemaak dat die Kommandant-generaal sy eie argiewe permanent moet bewaar nie. Voorts was daar reeds by die ontstaan van die Departement van Verdediging militêre argiewe wat ouer as dertig jaar was en nie meer vir die doeleindes van kantooradministrasie benodig was nie. Volgens die letter van die wet kwalifiseer hierdie argiewe dus sedertdien vir oorplasing na die Staatsargief.

Die oorplasing van militêre argiewe na 'n siviele argiefbewaarplek is egter deur die militêre owerhede as ongewens. beskou en wel om onderstaande redes:

(a) Weens die hoë sekerheidswaarde van die argiewe moet die vakkundige personeel lede van die Staande Mag wees 
en as sodanig onder die Reglement van Dissipline ressorteer.

(b) Argiefamptenare van die Staatsargief dra 'n ontoereikende kennis van die Suid-Afrikaanse Weermag en wat sy argiewe behels. Militêre kennis en agtergrond vir die argivaliese versorging van die argiewe is dus 'n absolute vereiste, selfs as die sekerheidsaspek buite rekening gelaat word.

(c) Die gespesialiseerde aard van die militêre dokumentasie maak dit feitlik onmoontlik vir argiefamptenare van die Afdeling Rekordbeheer, verbonde aan die kantoor van die Direkteur van Argiewe, om die betrokke argiewe te ondersoek vir die doeleindes van vernietigingsaanbevelings by die Argiefkommissie.

(d) Die Suid-Afrikaanse Weermag gebruik sy verlede ook baie meer as siviele departemente. Die Suid-Afrikaanse Weermag en sy argief vorm in dié opsig 'n funksionele eenheid.

(e) Ter aanvulling by die vorige paragraaf moet vermeld word dat militêre historici reeds aangestel was, om, met die nodige militêre agtergrond, die militêre geskiedskrywing van die Suid-Afrikaanse Weermag te behartig. Krygsgeskiedskrywing verskil van gewone geskiedskrywing oa in dié sin dat die krygshistorikus hom nie alleen by gebeure van vyftig jaar of ouer bepaal nie, maar al na gelang van die behoefte, ook resente gebeure moet beskrywe. Om hierdie rede moet hy toegang tot resente argiewe en selfs insae in nog lewende administratiewe lêers in enige afdeling van die Suid-Afrikaanse Weermag hê.

(f) In die meeste lande funksioneer militêre- en siviele argiefbewaarplekke apart.

(g) Ooreenkomstig artikel 9 van die Argiefwet sou militêre argiewe, indien dit na die Staatsargief oorgeplaas sou word, na vyftig jaar vir die publiek toeganklik gemaak word. Die Argiefwet maak wel voorsiening dat die verantwoordelike Minister, op grond van openbare beleid, kan gelas dat toegang tot sekere argiewe weerhou word. Die onus sou in so 'n geval by die Direkteur van Argiewe moes berus om aan te beveel watter argiewe oopgestel moet word en watter op grond van openbare beleid teruggehou moet word. Geredeneer kon word dat argiewe met 'n hoë sekerheidswaarde nie na die Staatsargief oorgeplaas hoef te word nie, terwyl die res dan wel oorgeplaas kan word. Dit kon wel gedoen word, maar nie sonder skending van die belangrike argiefekonomiese beginsel, nl dat die eenheid van 'n argiefgroep nie verbreek mag word nie.

Omdat dit duidelik was dat militêre argiewe nie na 'n siviele argiefbewaarplek oorgeplaas kon word nie, moes 'n oplossing gevind word ten opsigte van die wyse waarop sodanige oor- 
plasing verhoed kon word. Hierdie oplossing moes terselfdertyd die voordeligste argivale versorging van militêre argiewe verseker.

Die eerste twee moontlikhede wat oorweeg kan word, word in die woordomskrywing van argiewe in die Argiefwet gesuggereer. In die eerste instansie hoef sekere argiewe nie volgens hulle aard na 'n argiefbewaarplek (Staatsargief) oorgeplaas te word nie. Indien militêre argiewe volgens die aard (sekerheidsmotief) daarvan getakseer word, hoef dit dus nie na die Staatsargief oorgeplaas te word nie.

'n Tweede wyse van benadering sou wees om spesifieke wetsvoorsiening te maak sodat die Kommandant-generaal verantwoordelik sou wees vir die bewaring van militêre argiewe. 'n Praktiese voorbeeld in dié verband is artikel 3(a) van die Registrasie van Aktes Wet (Wet No 47 van 1937), wat bepaal:

Die registrateur moet, met inagneming van die bepalings van hierdie Wet alle stukke wat voor die inwerkingtreding van hierdie Wet tot die argief van die registrasiekantoor waarvoor hy aangestel is, behoort het of wat na daardie inwerkingtreding daarin opgeneem word, onder sy hoede neem en bewaar.

Derdens kon gehandel word in terme van artikel 5 (d) van die Argiefwet (Wet No. 6 van 1962), waarvolgens die Minister van Onderwys, Kuns en Wetenskap, met goedkeuring van die Minister van Finansies en op aanbeveling van die Direkteur van Argiewe, 'n militêre argiefbewaarplek kon stig.

Die eerste twee moontlikhede sou wel verhoed dat militêre argiewe na siviele argiefbewaarplekke oorgeplaas word, maar dit gaan mank aan 'n baie groot gebrek, nl. dat dit nie die masjinerie daarstel waarvolgens die Krygshistoriese Afdeling sy vakkundig-argivale funksie doeltreffend kon behartig nie. Die versorging van argiewe in die betrokke Afdeling het alle argivale aktiwiteite soos dokumente-administrasie, rekordbeheer, mikroverfilming, wetenskaplike ordening sowel as die fisiese versorging en bewaring van argiewe ingesluit. Verder ook die versorging van versamelings soos foto's en kaarte en die indeksering daarvan.

Dit was dus duidelik dat die betrokke Afdeling nie doeltreffend sonder die vakkundige leiding van die Direkteur van Argiewe sou kon funksioneer nie.

In die lig van voorafgaande het die Minister van Onderwys, Kuns en Wetenskap agv die beywering van die S.A. Weermag, op 16 Augustus 1967 kragtens artikel 5(d) van die Argiefwet sy goedkeuring aan die stigting van 'n afsonderlike militêre argiefbewaarplek verleen.

Met ingang van dieselfde datum is die benaming Krygshistoriese Afdeling deur dié van SAW Argief vervang. Die militêr-historiese en argivale bedrywighede van die voormalige Krygshistoriese Afdeling is ewenwel, om praktiese en organisatoriese redes, voorlopig nog saam beheer.

Op 14 Mei 1968 is 'n afsonderlike argiefbewaarplek vir die

Departement van Verdediging, onder die benaming $S A W$ 
Argief, volgens die onderstaande voorwaardes ingestel, tw. dat:

(a) Alle argiewe van die Departement van Verdediging na die SAW Argief oorgeplaas word.

(b) Die Departement van Verdediging sodanige argiewe ooreenkomstig die Argiefwet en -regulasies sal administreer.

(c) Die Departement van Verdediging die personeeladministrasie van sodanige Argiefbewaarplek sal behartig.

(d) Behoudens die bejalings van die Argiefwet en enige ander wet en onderworpe aan die voorwaardes, indien daar is, waarop enige aanwinste verkry is, het niemand toegang tot die argivalia wat in die SAW Argief berus nie, behalwe:

(i) Persone op die diensstaat van die Departement van Verdediging wat vrye toegang sal hê tot argivalia waar hulle dit in verband met navorsingswerk vir enige amptelike projek benodig.

(ii) Enige lid van die publiek wat deur die Direkteur van die Argiewe, in oorleg met die Departement van Verdediging, gemagtig word om insae in die onderhawige argiewe of aanwinste te verkry.

(e) Die publikasie van enige argivalia of oorspronklike bronne of enige verhandeling of ander navorsingsresultaat wat op 'n studie van enige argivalia of sodanige bronne gebaseer is, kan deur die Direkteur van Argiewe, in oorleg met die Departement van Verdediging, gemagtig word.

Op 29 Julie 1968 is die SAW Argief as identiteit saam met ander bestaande militêr-historiese funksies van die eertydse Krygshistoriese Afdeling, onder die nuwe, allesomvattende onderafdelingsbenaming, Militêr-Historiese en Argivale Dienste ingeskakel. Laasgenoemde is 'n onderafdeling, ressorterende onder die Hoof van Personeel. 


\section{ORGANISATORIESE DOELSTELLING VAN DIE MILITÊR- HISTORIESE EN ARGIVALE DIENSTE}

Die primêre funksie van die Militêr-Historiese en Argivale Dienste is militêr-histories en -argivalies, maw die bewaring, beheer, versorging en bewerking van militêr-historiese bronnemateriaal, om in alle opsigte militêr-histories en argivalies van diens vir die Departement van Verdediging, ander staatsdepartemente en inrigtings en die publiek in die algemeen te wees.

Uit die voorafgaande is dit duidelik dat die funksionele struktuur van die Militêr-Historiese en Argivale Dienste in twee hoofkomponente uiteenval, tw die Argief met sy militêre argiefkundige vakrigting en die militêre geskiedkundige rigting, in die besonder die militêre geskiedskrywing.

Omdat in die aard en samestelling van Militêr-Historiese en Argivale Dienste twee afgebakende en gespesialiseerde vakrigtings te onderskei is, het die Onderafdeling noodwendig 'n tweeledige organisatoriese doelstelling tw die administrasie van die argiewe van die Departement van Verdediging en die militêr-historiese doelstelling.

\section{a. Administrasie van die argiewe van die Departement van Verdediging}

Die doel van die Argiefadministrasie kan gestel word as die metodiese bewaring, beheer en versorging van die argiewe van die Departement van Verdediging, ten einde te verseker dat die permanent waardevolle argiewe van die Departement op 'n doeltreffende wyse vir administratiewe naslaan- en militêr-historiese doeleindes, in besonder militêre geskiedskrywing, bewaar word. Met die argivale doelstelling gedefinieer, kan die waarde van doeltreffende Argiefadministrasie kortliks aan die hand van onderstaande soos volg toegelig word:

i. 'n Leidende argivaris het eens opgemerk dat die beskawingspeil van 'n volk bepaal kan word ooreenkomstig die wyse waarop so 'n volk sy argiewe bewaar en versorg. Hierdie stelling is geensins te betwyfel nie en kan kortliks aan die hand van enkele historiese voorbeelde toegelig word. Die hoogstaande antieke beskawings van die Mesopotamiërs $( \pm 1700$ v.C), die Grieke $( \pm 500$ v.C) en die Romeine $( \pm 300$ v.C) het reeds in hierdie vroeë jare almal een of ander vorm van 'n georganiseerde argiefdiens gehad. In teenstelling hiermee was in die primitiewer beskawing van Afrika tot en met die koms van die Europeërs na hierdie vasteland, weinig, indien enige, sprake van staatsdokumentasie. Die bewaring en versorging van argiewe het in hierdie beskawings geen aandag geniet nie.

ii. As dit dan in die vorige eeue nodig was om staatsdokumente (argiewe) te bewaar en te versorg, is dit in ons moderne eeu soveel te meer 'n noodsaaklikheid. Trouens, dit is belangrik om te weet dat die argiefdiens in die moderne staatsadministrasie die rol vervul van die geheue van die staat te 
wees. Indien 'n staat se argiefdiens dus swak georganiseer is, kan so 'n staat nie ,onthou" nie en kan hy gevolglik nie doeltreffend funksioneer nie.

iii. Dieselfde maatstawwe wat vir 'n staat geld, is natuurlik ook van toepassing op 'n departement en in hierdie geval by name die Departement van Verdediging.

\section{b. Militêr-historiese doelstelling}

Ten einde die dieper betekenis van die primêre funksie van die Onderafdeling te deurgrond is dit nodig om te weet wat ,geskiedenis" en in besonder „militêre geskiedenis" is, om dan so die plek daarvan in die funksionele struktuur van die Onderafdeling te bepaal.

i. Wat is Geskiedenis? Die begrip geskiedenis sluit die volgende in:

(a) Gebeurtenisse van die verlede waarby die mens betroklse was.

(b) Die beskrywing of die verslag doen daarvan.

(c) Die werkwyse of tegniek om bogenoemde verslag op te stel.

\section{ii. Die middelpunt van die geskiedenis}

(a) In die middelpunt van die geskiedenis bly steeds die historiese persoonlikheid en die samelewing en die wisselwerking tussen dié twee. Sowel die ,groot man” as die massa maak geskiedenis.

(b) Waar 'n gewone mens onder moeilike omstandighede 'n daad verrig wat vir 'n groep van belang is, word hy 'n held. Dan dien hy as voorbeeld vir die gemeenskap as gevolg van sy goeie hoedanighede (Staatspresident S.J.P. Kruger, Andries Pretorius, John Chard, Louw Wepener, Florence Nightingale, Danie Theron, ea).

iii. Die omvang van die geskiedenis

(a) Tyd. Ons reken tot die geskiedenis dié tydperik wat dateer vanaf die invoering van die skrif, maw vanaf die tyd dat die mense hul gedagtes, dade en herinneringe op skrif begin opteken het, tot vandag toe. Wat voor dié tyd gebeur het, is voorgeskiedenis. Die tyd is een van die faktore wat die omvang bepaal.

(b) Die breedte. Die veld van die geskiedenis brei ook in die breedte uit, deurdat as gevolg van nuwe ontdekkings en voortgesette navorsing meer gegewens oor 'n bepaalde onderwerp gevind word. Vandag is ons kennis oor die Groot Trek aanmerklik meer as sê 'n halwe eeu gelede.

(c) Binne hierdie veld is daar kleiner gebiede wat indelings regverdig. Ons kan die geskiedenis van 'n mens, 'n familie, 'n wyk, of 'n distrik bestudeer. Meesal bestudeer ons 'n volk of 'n staat (Egiptenare en hul staat, Afrikaners en hul Voortrekkerstate.) Ons kan die ontwikkeling van ' $n$ stad, die ontwikkeling van die vissery in 
ons land, die ontwikkeling van die mode, die oorsake van die Groot Trek, die geskiedenis van die SA Weermag, en die gevolge van Jan van Riebeeck se stigtingsdaad aan die Kaap bestudeer.

iv. 'n Gespesialiseerde wetenskap

(a) Veral tydens die vorige eeu het navorsers en skrywers die geskiedenisbeoefening as 'n wetenskap begin beskou en tot spesialisering oorgegaan. Dit verklaar dat ons vandag o.m. te doen kry met: Staatkundige geskiedenis, ekonomies geskiedenis, kultuurgeskiedenis, kunsgeskiedenis en militêre geskiecienis.

(b) Die volgende indeling wys op 'n ander verdeling van die werkgebied en studieterrein: Antieke geskiedenis, moderne geskiedenis, kontemporêre geskiedenis, wêreldgeskiedenis, vaderlandse geskiedenis.

\section{v. Die belang van geskiedenis en geskiedkundige kennis}

(a) Sowel die bestudering van die geskiedenis deur die navorser as deur die landsburger, en dit geld veral vir die vaderlandse geskiedenis, is van besondere belang.

(b) Dit leer, gesien in terme van tyd en plek, die volwaardige landsburger sy vastrapplek te midde van sy eie volk ken. Dit laat hom bewus word van sy herkoms, sy hedendaagse taak en besieling en sy verantwoordelikhede teenoor die volksgemeenskap, dié waarvan hy 'n we like en denkende, idealiserende en strydbare lid vorm. Dit sal hom tewens, as 'n lid van dieselfde gemeenskap, die nodige geestelike weerbaarheid verskaf.

(c) Geskiedenis, en veral die beoefening van ons vaderlandse geskiedenis in sy menigvuldige vertakkings, sal en moet op dié wyse 'n groot $\mathrm{krag}$ in die lewe van ons volk word.

(d) 'n Kerngesonde, tradisievaste en lewenskragtige volk ken sy verlede, put lesse daaruit, hou koers in die hede en beplan, met erkenning van die voortdurende leiding van die Allerhoogste, sy toekoms op dié hegte grondslae.

\section{vi. Militêre geskiedenis}

(a) Geskiedenis is die wetenskap wat die verskynsels van die lewe probeer beskryf en herbelewend verklaar vir sover dit veranderinge geld wat die mens se verhouding teenoor sy samelewing laat ontstaan; die geskiedenis probeer dit te bereik deur hierdie veranderinge uit die oogpunt van hul uitwerking op die daaropvolgende tydvak of met betrekking tot hul kenmerkende eienskappe uit te kies en hom op dié veranderinge toe te spits wat onherhaalbaar en uniek is weens hul assosiasie binne 'n gegewe tydsverband en 'n besondere gebied.

(b) Militêre geskiedenis is 'n onderdeel, 'n besondere gebied van die geskiedenis. Dit is wat die studie en die skryf daarvan betref, 'n objektiewe, akkurate, beskrywende en verklarende wetenskaplik verantwoorde weergawe van 
al die bedrywighede, sowel in tye van vrede as oorlog, van die gewapende magte.

(c) Doelstellings van die studie en daarstelling van militêre geskiedenis is om binne Weermagsverband die besef te laat groei en algemeen te laat aanvaar dat militêre geskiedenis, bo alles die vaderlandse militêre geskiedenis, 'n basiese bron van kennis is om vraagstukke op te los en vooruitgang, sowel in teorie as in die praktyk, van die rnilitêre wetenskap te bewerkstellig, om militêre geskiedenis aanhoudend en ten volle in alle militêre bedrywighede te benut en op dié wyse:

(i) Leerstellings ooreenkomstig die vereistes van die moderne oorlog neer te lê.

(ii) Opleidings- $€ n$ vakkundige kundighede te verstrek.

(iii) Die hoogste mate van indiwiduele en organisatoriese militêre moraal, dissipline, nasionalisme, patriotisme en besieling daar te stel.

(iv) Die lede van die volk, die gewapende magte en ander in te lig oor die verlede van die gewapende magte.

vii. Die gebruik van militêre geskiedenis

(a) Die verstaan van die aanwending van geskiedenis om militêre vraagstukke op te los, vereis kennis van die waarde van militêre geskiedenis, sy bronne en vorms.

(i) Die waarde van militêre geskiedenis vloei uit die stelling voort dat kennis mag beteken en van die aard van militêre geskiedenis as 'n bepaalde soort kennis. Hoe meer deeglik verwerkte kennis ter beskikking gestel word, hoe groter die kans dat huidige en toekomstige militêre vraagstukke, waarvan die antwoord of 'n gedeelte daarvan op dié besondere kennis berus, geheel of gedeeltelik opgelos kan word.

(ii) Die bronne van die militêre geskiedenis is, soos al die ander in die geskiedenis, gebeurtenisse waarby die mens betrokke was. Dit is die feite waaruit dié gebeurtenisse bestaan wat 'n besondere soort van kennis vereis om vordering op die gebied van die militêre wetenskap te kan maak.

(iii) Die vorms waarin militêre geskiedenis voorhande is, varieer van onbewerkte feite, dokumente soos dagboeke edm., tot gepubliseerde weergawes.

(iv) Afgesien van die vorms waarin militêre geskiedenis beskikbaar is, is die studie daarvan gebiedend vir 'n suksesvolle militêre loopbaan. Aangesien die meeste kennis deur lees en studie en nie deur persoonlike ondervinding verkry word nie is militêre geskiedenis die beste bron van gespesialiseerde kennis wat vir die ywerige en verantwoordelike militêre vakkundige beskikbaar is. Hy kan dié kennis benut as 'n bron van empiriese gegewens waaruit beginsels en prosedure afgelei kan word; as 'n substituut 
vir persoonlike ervaring; as feitemateriaal om die sielkundige kloof tussen die werklike en die ingebeelde te oorbrug; en as 'n grondslag om die huidige behoeittes op grond van dié verlede te probeer bepaal; om nuwe dogmas (leerstellings) neer te lê wat, gegrond op die kennis omtrent die verlede, as logiese riglyne vir die hede en die toekoms kan dien; om beplanning gedeeltelik op voorbeelde van die verlede te baseer; en om sy opleidings- en vakkundige bekwaamheid te verbeter.

(v) Die uiteindelike doelwit met betrekking tot die ontwikkeling van die moraal en die gees in militêre verband, is die aankweek van 'n organisatoriese moraal en gees binne die raamwerk waarvan die enkeling sy eie belang vrywillig aan die doelstellings van die groep se organisasie onderwerp.

(vi) Organisatoriese geskiedenis en verwante bedrywighede moet gebruik word om die militêre organisasie as 'n lewende eenheid daar te stel. Geboorte- en sterfdatums, verjaarsdae, herdenkings, geboue, die voorgeslag, suksesse en teenslae moet dien om dis militêre bande te versterk. Heldedade en eerbare diens in die verlede moet as maatstawwe vir die hede en die toekoms dien.

(vii) Militêre geskiedenis is een van die nuttigste middels om sowel die publiek as die weermagslede in te lig. Deur militêre oorwinnings, ontberings en suksesse van die verlede as essensiële bestanddele van ons militêre-, sosiale- en kulturele erfenis bekend te stel, word hulle bronne van besieling en persoonlike trots wat aangewend kan word om 'n groot aantal militêre doelstellings te verwesenlik. Ooreenkomstig dié beginsels moet militêre geskiedenis, waar doenlik, op die volgende wyses bekend gestel word:

In die vorm van gedrukte publikasies van uiteenlopende omvang en gehalte, in die vorm van uitstallings, by geleentheid van besondere militêre- en burgerlike geleenthede, in die vorm van toesprake en lesings, deur middel van nuusberigte en in die vorm van nuusverhale en radioprogramme. 


\section{FUNKSIES VAN MILITÊR-HISTORIESE EN ARGIVALE DIENSTE}

Die funksies van die Militêr-Flistoriese en Argivale Dienste is soos volg:

\section{a. Argivale Dienste}

i. Rekordbeheer (oorplasing en vernietiging van argiewe).

(a) Oorplasing van argiewe van die Departement van Verdediging ooreenkomstig die Argiefwet.

(b) Afhandeling van roetine vernietigingsaansoeke (beperkte en staande magtigings).

(c) Beskikkingsmagtigings tov liasseerstelsels van die Departement van Verdediging.

(d) Rekords hou tov magtigings verleen.

ii. Beheer, Bewaring en Versorging van Argiewe

(a) Ordening en beskrywing van argiefgroepe.

(a) Beheer en bewaring van argiewe.

iii. Byeenbring, Bewaring, Versorging en Beheer van Aanvutlende Versamelings

(a) Fotoversameling. Versamel, identifisering, katalogisering, standaardisering, liassering en indeksering van foto's.

(b) Mikrofilmversameling. Selektering van materiaal vir mikroverfilming $\in$ n lysing van sodanige materiaal.

(c) Kaartversameling. Katalogisering en indeksering van kaarte.

(d) Ander versamelings. Plaatopnames, bandopnames, kleurskyfies, ens. Katalogisering en indeksering van sodanige versamelings.

(e) Aanwinste. Insameling, registrasie, indeksering en berging van aanwinste.

(f) Interne Biblioteek.

(g) Amptelike publikasies.

iv. Leeskamerbeheer. Toesig oor navorsing en toepassing van argiefregulasies in dié verband.

v. Onderwerpsindeksering van amptelike publikasies, tydskrifte, argiefgroepe en aanwinste.

\section{b. Algemene Dienste}

i. Historiese Dienste

(a) Beantwoording van militêr-historiese navrae aan alle vertakkings van die Departement van Verdediging, ander staatsdepartemente en inrigtings en die publiek in die algemeen.

(b) Koördinering van militêr-historiese informasie en bedrywighede in verband daarmee in die Departement van Verdediging. 
(c) Eenheidsgeskiedenisse.

(d) Koerantknipselversameling. Selektering, montering en indeksering van koerantknipsels.

(e) Gevegsonderskeidings.

(f) Oorlogsgrafte.

(g) Naamgewing.

(h) Veldwerk.

ii. Administratiewe Dienste

(a) Administrasie tov Persoonlike lêers WOI, Protesterende Burgers WOI, WOII, Italiaanse Krygsgevangenes WOII, Staandemag, Burgermag, Kommando's en Kadette en Interne Administrasie van Militêr-Historiese en Argivale Dienste.

(i) Byeenbring, bewaring, versorging en beheer van persoonlike lêers.

(ii) Administrasie daaruit voortspruitende.

(iii) Opberging en uitreiking van medaljes WOI en WOII.

(iv) Behartiging van alle administratiewe aangeleenthede tov interne administrasie van die Militêr-Historiese en Argivale Dienste, insluitende personeelaangeleenthede.

\section{Geskiedskrywing}

1. Suiwer wetenskaplike geskiedskrywing, bedoel vir vakkundiges, te publiseer in vakkundige publikasies of in die vorm van afsonderlike publikasies wat deur die Departemen van Verdediging uitgegee word.

ii. Populêr-wetenskaplike geskiedskrywing in die vorm van bydraes vir koerante, tydskrifte en/of radio, of in die vorm van afsonderlike publikasies wat deur die Departement van Verdediging uitgegee word.

iii. Redaksie en publikasie van geskikte militêr-historiese materiaal en navorsingsresultate.

iv. Bronnestudie en opname van militêr-historiese materiaal sover dit die Departement van Verdediging raak.

v. Diverse projekte. Beantwoording van omvangryke historiese navrae, opstel van konseptoesprake, opstel en hou van lesings, veldwerk. 


\section{BELANGRIKE ARGIVALIA IN DIE SAW ARGIEF}

\section{a. Argiewe}

'n Groot gedeelte van die argiewe in die SAW Argief bestaan uit persoonlike lêers. Hierdie lêers is eintlik nie argiewe wat in 'n argiefbewaarplek tuishoort nie, in dié sin dat hulle nog administratief in gebruik is, en verder, dat personeel aan die SAW Argief se diensstaat verbonde, hierdie administrasie behartig. Hierdie toedrag van sake vloei voort uit die ontwikkeling van die bewaarplek.

Die persoonlike lêers wat in die bewaarplek gehuisves word, kan in onderstaande groepe ingedeel word:

i. Persoontike lêers tov Eerste Wêreldoorlog

(a) WOI - vrywilligers. Blank sowel as nie-blank

Die sentralisasie van oorlogsargiewe onder die Stafoffi. sier Oorlogsregisters, het tot gevolg gehad dat die verskillende soorte persoonlike lêers tov WOI - vrywilligers byeengebring en in een omslag gekonsolideer is. Die belangrikste neerslag van die vermelde kantoor is dan ook die volledige stel persoonlike lêers tov WOI -vrywilligers.

Ten gevolge van die aktiwiteite van die eertydse Afdeling Oorlogsregisters (1914 - 1927) is ook ander belangrike bronne nagelaat wat verband hou met die WOI - vrywilliger personeellêeradministrasie. Daar is byvoorbeeld 'n volledige stel registers opgestel waarin eretoekennings, veldtogsterre, medaljes en dekorasies ten opsigte van elke vrywilliger aangedui is, asook 'n gespesifiseerde ongevallelys wat volgens korps- en eenheidsindeling opgestel is.

(b) Protesterende Burgermag

Hierdie groep lêers is die lêers van lede van die Protesterende Burgermag (Rebelle) wat gedurende die Gewapende Protes gevange geneem is teen wie deur die Hoofprovoos (,Provost Marshal”) opgetree is.

ii. Persoonlike leers ten opsigte van die Tweede Wêreldoorlog Die Afdeling Oorlogsregisters (1939 - 1959) se belangrikste dokumenteneerslag was die volledige groepe persoonlike lêers tov.

(a) Blanke vrywilligers en „Cape Corps”.

(b) Indiër- en Maleier Korps.

(c) Naturelle Militêre Korps.

(d) Deeltydse Burgermag en Nasionale Reserwe Vrywilligers.

(e) Krygsgevangenes.

iii. Vredestydse persoonlike lêers

Onder hierdie kategorie ressorteer die persoonlike lêers van persone wat in die verlede op die SAW-diensstaat was, maar 
om verskillende redes nie meer aan die SAW verbonde is nie. In hierdie verband word die volgende groepe persoonlike lêers in die SAW Argief gehuisves en geadministreer:

(a) S.A. Berede Skutters.

(b) Spesiale Diensbataljon.

(c) Staande Mag- en Burgermagoffisiere.

(d) Kommando-offisiere.

(e) Kadetoffisiere.

(f) Staande Mag-manskappe.

(g) Burgermag-manskappe.

1v. Ander argiewe

Die begrip ander argiewe word in hierdie verband slegs gebruik om dié argiewe te onderskei van die persoonlike lêers in die bewaarplek. Vir die doeleindes van bespreking kan hierdie argiewe onder die volgende hoofde behandel word.

(a) Argiewe tov die Eerste Wêreldoorlog

Betreffende die argiewe van hierdie periode is die bewaarplek slegs in besit van die administratiewe neerslag van die kantore aan die Verdedigingshoofkwartier te Pretoria. Die belangrikste deel van oorlogsdokumentasie, naamlik die operasionele dokumenteneerslag, ontbreek feitlik heeltemal ten opsigte van die Eerste Wêreldoorlog.

Hierdie ongelukkige toedrag van sake moet toegeskrywe word aan die feit dat die Suid-Afrikaanse troepe gedurende die Eerste Wêreldoorlog 'n integrale deel van die Imperiale magte gevorm het en dat die meeste oorlogsdagboeke van hierdie oorlog aan die Britse owerhede oorhandig is.

Die bewaarplek is egter in besit van afskrifte van oorlogsdagboeke van die Suid-Afrikaanse Infanteriebrigade wat in Frankryk geveg het. Hierdie afskrifte is vermoedelik in latere jare vanuit Engeland ontvang.

Die gebrek aan operasionele dokumentasie vir dié tydperk word egter enigermate aangevul as gevolg van die feit dat Suid-Afrikaanse eenhede wat gedurende die oorlog in Imperiale diens was, ooreenkomstig „Kings Regulations" no. 1930 en 1931, geskiedkundige verslae aangaande die eenheidsaktiwiteite gedurende die oorlog moes opstel. Hoewel waardevol, gaan hierdie verslae mank aan die gebrek dat hulle oorsigtelike verslae is en nie 'n daaglikse verslag soos 'n oorlogsdagboek nie.

(a) Argiewe tov die Tweede Wêreldoorlog

Ten opsigte van die argiewe daterende uit die Tweede Wêreldoorlog, is die bewaarplek in die gelukkige posisi? om, benewens die administratiewe dokumentasie, 'n bykans volledige operasionele dokumentasie in besit te hê. Vanaf 1921, met die onttrekking van die Britse magte uit Suid-Afrika, het die Suid-Afrikaanse Weermag onafhanklik begin funksioneer.

In die Tweede Wêreldoorlog het die Suid-Afrikaanse troepe dus nie soos in die Eerste Wêreldoorlog as Imperiale troepe opgetree nie, maar onder Suid-Afrikaanse 
bevel geveg. Op hul beurt was die Suid-Afrikaanse bevelvoerders egter ondergeskik aan die Britse Opperkebevel.

Die oorlogsdagboeke en die daartoe behorende operasionele dokumente is gedurende die Tweede Wêreldoorlog direk aan Verdedigingshoofkwartier te Pretoria gestuur. Gevolglik huisves die bewaarplek 'n bykans volledig stel dagboeke vir al drie die weermagsdele tot op divisievlak. Dagboeke vir formasies hoër as divisievlak berus in die Britse Oorlogsargiefbewaarplek.

(c) Argiewe van Hoofkwartierafdelings

Die Departement van Verdediging was vanaf sy ontstaan georganiseer in 'n Hoofkwartierstaf en 'n gedesentraliseerde distriksadministrasie.

Die Hoofkwartierstaf is gevorm deur die verskillende militêre afdelings aan Verdedigingshoofkwartier wat sedert 1919 onder die Hoof van die Generale Staf (die latere Kommandant-generaal) gekoördineer is. Benewens die Hoof van die Generale Staf, het die Hoofkwartierstaf bestaan uit die verskillende Stafhoofde dus die Hoofde van die Leër, Lugmag en Vloot - en verder uit Afdelingshoofde soos die Adjudant-generaal, Kwartiermeester-generaal en Direkteur van Tegniese Dienste.

Weens die feit dat die Hoofkwartierstaf, net soos die Opperbevel vandag, die beleidsvormende instansie was, het elkeen van hierdie argiefgroepe 'n baie hoë navorsingswaarde. Die krygsverrigtinge gedurende die twee wêreldoorloë uitgeslote, word elke faset van die ontwikkeling van die Suid-Afrikaanse Weermag feitlik volledig in die argiewe van die onderskeie onderhawige kantore weerspieël.

Soos uit voormelde afgelei kan word, is die belangrikste argiewe in hierdie verband dié van die Hoof van die Generale Staf, die Adjudant-generaal, die Direkteur van Tegniese Dienste en die Hoofde van die Leër, Lugmag. en Vloot.

Omdat die Sekretaris van Verdediging sedert die ontstaan van die Suid-Afrikaanse Weermag in 1912 die permanente hoof van die departement was, sal die hoofkwartierargiefgroepe alleen heeltemal volledig wees wanneer dit neffens die argief van die Sekretaris van Verdediging geraadpleeg word.

\section{b. Aanvullende versamelings}

Soos alle openbare argiefbewaarplekke in die Republiek, huisves die SAW Argief ook die gewone aanvullende versamelings soos private aanwinste, 'n interne biblioteek, amptelike publikasies, 'n fotoversameling, 'n mikrofilmversameling en 'n kaartversameling. Hierdie versamelings word elkeen volgens 'n eiesoortige wetenskaplike metode bewaar en versorg.

Elkeen van hierdie versamelings bevat belangrike aanvullende 
informasie tot die argiewe in die bewaarplek. Vir die navorser is dit belangrik om van veral drie van hierdie versamelings kennis te neem, tw: die fotoversameling, die interne biblioteek en die koerantknipselversameling.

Die fotoversameling bestaan uit ongeveer 30,000 foto's en negatiewe met 'n militêre strekking, wat strek oor die periode vanaf die eerste Suid-Afrikaanse militêre aktiwiteite tot ons eie tyd. Omdat die inhoud van 'n fotoversameling moeilik beskryf kan word sonder om afbreuk aan een of ander aspek daarvan te doen, kan volstaan word deur te sê dat die grootste hoeveelheid foto's uit die Anglo-Boere-oorlog, die Eerste- en Tweede Wêreldoorlog dateer.

Die interne biblioteek is, soos die naam aandui, nie 'n uitleenbiblioteek nie, maar is slegs bedoel om deur personeellede in die uitvoering van hulle pligte gebruik te word. Biblioteekmateriaal word egter vryelik aan navorsers ter plaatse beskikbaar gestel.

Benewens materiaal soos Argiefkommissie-publikasies, ensiklopedieë, woordeboeke en ' $n$ reeks vindmiddels wat eie is aan alle argiefbiblioteke, bevat die interne biblioteek net oor die vierhonderd boeke en 'n waardevolle reeks pamflette. Die boeke is 'n seleksie van militêr-historiese werke en vanweë die gespesialiseerde versamelingsveld bestaan die boekery uit 'n betreklike hoë persentasie militêr-historiese Africana.

Betreffende die koerantknipselversameling kan opgemerk word dat die bewaarplek besig is met die opbou van 'n knipselversameling, waarvan die knipsels uit 'n seleksie van sowat 42 verskillende koerante verkry word en waarvan die neerslag van 'n suiwer militêr-historiese aard is.

Die knipsels word op so 'n wyse gemonteer, geberg en geïndekseer dat dit feitlik onmiddellik teruggevind en indien nodig 'n afdruk daarvan gemaak kan word. 


\section{FUNKSIONELE BENUTTING VAN DIE MILITÊR-HISTO- RIESE EN ARGIVALE DIENSTE}

\section{a. Militêr-Historiese en Argivale Dienste}

i. Algemene Dienste

(a) Ander argiefbewaarplekke kan hulle argiewe, binne die raamwerk van die toeganklikheidsbepalings van die Argiefwet, vryelik tot beskiking van personeel van Staatsdepartemente en/of die publiek in die algemeen stel en sodanige navraers versoek om hulle navorsing self te doen. Die sekerheidsmotief in aanmerking genome, is die personeel van die SAW Argief daarop aangewese om die grootste gedeelte van navorsingswerk wat uit militêr-historiese navrae mag voortspruit, self te onderneem en die verlangde informasie in so ' $n$ vorm te verstrek dat militêre sekerheid nie in gedrang kan kom nie.

Weens die groot hoeveelheid navrae wat van die verskillende afdelings van die Departement van Verdediging, ander Staatsdepartemente, of die publiek hier en ook uit die buiteland ontvang word, is spesifieke personeelvoorsiening gemaak om hierdie diens te kan lewer.

Een van die hooffunksies van die argivaris in beheer van argivalia en leeskameraktiwiteite is die beantwoording van minder omvangryke militêr-historiese navrae, die koördinering van militêr-historiese informasie en bedrywighede in verband daarmee in die Suid-Afrikaanse Weermag. In die uitvoering van hierdie funksie word die betrokke argivaris bygestaan deur gegradueerdes met BA-grade en met geskiedenis as een van die hoofvakke. Militêr-historiese navrae handel gewoonlik oor enige aspek rakende die Suid-Afrikaanse militêre geskiedenis.

Nou verbonde aan die beantwoording van militêr-historiese navrae, is die spesifieke dienste wat aan die Departement van Verdediging self gelewer word.

Sodanige dienste sluit o.a. die byhou en administrasie van eenheidsgeskiedenisse van alle Suid-Afrikaanse militêre eenhede, die verstrekking van informasie aangaande oorlogigrafte en die advisering in verband met aangeleenthede soos die toekenning van gevegsonderskeidings aan Suid-Afrikaanse militêre eenhede en naamgewing tov militêre geboue, -gebiede edm in.

ii. Geskiedskrywing

Militêre geskiedskrywing is een van die hooffunksies van die Onderafdeling. Een aspek van militêre geskiedskrywing wat dikwels uit die oog verloor word, dien hier vermeld te word. Dit is die dienste wat die militêre historici aan die Militêre Akademie en ander opleidingsinrigtings lewer in die vorm van die beskikbaarstelling van navorsingsresultate 
wat deur gemelde inrigtings as studiemateriaal aangewend word. Voorts word ook dienste soos die opstel van konseptoesprake, die opstel en hou van lesings, ens deur die militêre historici gelewer.

\section{b. Navorsing}

Dokumente besit eers argivale kwaliteit wanneer hulle bewaar word vir redes behalwe dié waarvoor hulle geskep is, dus, as hulle navorsingswaarde besit. Om hierdie rede kan alle argiefbewaarplekke as openbare navorsingsinrigtings beskou word.

Omdat die SAW Argief ook oor navorsingsfasiliteite beskik, is dit gewens om onder die militêr-historiese dienste by wyse van afsluiting ook op die toeganklikheidsbepalings tov militêre argiewe te wys.

Die onderstaande toeganklikheidsbepalings is tans van toepassing :

i. Alle argiewe in die SAW Argief is vir insae gesluit.

ii. Militêre en burgerlike lede op die vaste diensstaat van die Staande Mag wat amptelik navorsingswerk verrig, het vir dié doel vrye toegang tot die argiewe, met dien verstande dat goedkeuring vir die onderwerp, sowel as tov die persoon wat dit onderneem, vooraf van die Hoof van Personeel verkry moet word.

iii. Wanneer dié kategorie lede in voorafgaande paragraaf vermeld, navorsing vir private doeleindes wil doen, dan moet goedkeuring daarvoor van die Minister van Nasionale Opvoeding verkry word. (Sien bladsy $26^{*}$ ).

iv. Alle ander persone wat in verband met navorsingswerk vir enige ander projek, hetsy amptelik al dan nie, toegang tot die argiewe wil hê, moet toestemming daartoe van die Minister van Nasionale Opvoeding verkry.

Ten opsigte van die prosedure wat gevolg word om insae te verkry in argiewe wat in die SAW Argief berus, geld die volgende beleidsvoorskrifte:

(a) By aansoeke om insae in militêre argiewe te verkry, moet die volgende besonderhede verstrek word: Wie die navorsing gaan onderneem, asook agtergrondsfeite insake die persoon se loopbaan, met spesifieke verwysing na sy persoonlike integriteit en vorige ondervinding van geskiedskrywing; die onderwerp en omvang van die beoogde navorsing; die doel van die navorsing en wat met die navorsingsproduk beoog word, sowel as die argiewe wat die navorser in die SAW Argief wens te raadpleeg.

(b) Vertoë aan die Minister van Nasionale Opvoeding moet deur die kantoor van die Direkteur van Argiewe gerig word.

\section{v. Administratiewe Dienste}

Die Administratiewe dienste wat die Onderafdeling lewer, staan in verband met die administrasie van persoonlike lêers. Die belangrikste en ongetwyfeld die omvangrykste van hierdie dienste is die verskaffing van diensstate en die uitrei- 
king van medaljes aan oud-vrywilligers van die Eerste- en Tweede Wêreldoorlog.

As gevolg van 'n Parlementsbesluit dat Protesterende Burgers op 'n oorlogspensioen geregtig is, word die persoonlike lêers uit die Argief van die Hoofprovoos tans baie gebruik om lede van die Protesterende Burgermag van bewyse van deelname aan die Gewapende Protes te voorsien.

1. In November 1919 was die posisie m.b.t. persoonlike lêers dat dit uit ses hoofgroepe bestaan het en deur drie verskillende instansies geadministreer is. Die groepe was die volgende:

a. Suidwes-Afrikaveldtog - persoonlike lêers.

b. Oos- en Sentraal-Afrika - persconlike lêers.

c. Oorsese Kor'ígente - persoonlike lêers.

d. U.V.M. personeel - persoonlike lêers.

e. Imperiale dienskontigente in die Unie - persoonlike lêers.

f. Naturelle arbeidskontigente - persoon!ike lêers.

Die Adjudant-generaal het groepe a en d geadministreer. Die Hoof van die Hoofregistrasiekantoor het groepe b, c en e geadministreer, terwyl die Departement van Naturellesake groep $f$ geadministreer het. Hierbenewens was die Bewaarder van Oorlogsargiewe ook nog in besit var' 'n groot hoeveelheid persoonlike lêers van eenhede.

2. Onder siviele argiewe is verstaan die argiewe van die kantoor van die Sekretaris van Verdediging, terwyl militêre argiewe die res van die Departemer: van Verdsdiging se argiewe ingesluit het.

* Die betrokke artikel lui tans, Julie 1969, in terme van die Wysigingswet op Argiewe (Wet No. 63 van 1969), soos volg:

,,(7) Toegang tot argiewe met betrekking tot die Suid-Afrikaanse Weermag of verdedigingsaangeleenthede in bewaring van 'n argiefbewaarplek word nie sonder die goedkeuring van die Minister wat in oorleg met die Minister van Verdediging optree, gemagtig nie." 